\title{
Establishment of physical environment in solid state fermentation for the production of glucoamylase using Box-Behnken design
}

\author{
Bilqees Fatima, Mahmood Ali Khan and Zahid Hussain ${ }^{\star}$ \\ Institute of Industrial Biotechnology (IIB), GC University Kachery Road Lahore 54000, Pakistan. \\ Email: zahid biotech@yahoo.com
}

Received 19 April 2014; Received in revised form 14 September 2014; Accepted 15 September 2014

\begin{abstract}
Aims: Glucoamylase is an industrially important enzyme and is second to the proteases in worldwide distribution and sales among industrial enzymes. The aim of this study was to maximize its production from a GRAS strain Aspergillus oryzae IIB-6 using cheap medium by solid state fermentation.

Methodology and results: Different carbon and nitrogen sources were evaluated as an additional supplement to wheat bran. The response surface methodology (RSM) was employed for optimization of most important physical parameters viz., $\mathrm{pH}$, temperature and inoculum density as their monitoring is very difficult because of the solid nature of the substrate. Box-Behnken factorial design based on three levels and three variables was employed to obtain optimal combination of three independent variables. Maltose and peptone were found to be the best additional carbon and nitrogen sources. The optimal conditions for $\mathrm{pH}$, temperature and inoculum size were $5.29,36.2{ }^{\circ} \mathrm{C}$ and $17.7 \%(\mathrm{v} / \mathrm{w}$ ), respectively as prescribed by second-order polynomial quadratic model. Under optimized conditions, the experimental value of enzyme activity was $7750.02 \mathrm{U} / \mathrm{gds}$, which is very close to $7713.04 \mathrm{U} / \mathrm{gds}$ predicted by the model. $\mathrm{R}^{2}$ was 99.99\% which indicates a good agreement between experimental and predicted values.

Conclusion, significance and impact of study: The analysis of variance showed that $p$-values of the coefficients for linear effects and square effects of all the variables were $<0.0001$, suggesting these variables are highly significant for the enzyme production. Overall $23.01 \%$ increase in enzyme production was achieved by RSM optimization which can be proposed for food and pharmaceutical industries.
\end{abstract}

Keywords: Glucoamylase, Aspergillus oryzae, physical parameters, Box-Behnken factorial design, Response Surface Methodology.

\section{INTRODUCTION}

Glucoamylase (GA, EC 3.2.1.3) is an industrially important enzyme that release glucose from non-reducing end of starch and related oligosaccharides, involving in hydrolysis of $\alpha-1,4-$ glycosidic linkage faster than $\alpha-1,6$ and $\alpha-1,3$ linkages (Gudi et al., 2013). GA currently used in food and pharmaceutical industries, in the production of glucose syrup, high fructose corn syrup and alcohol. Although it can be produced from variety of organisms; however, filamentous fungi have a great potential for extracellular production of this enzyme (Zambre, 2010). GA is exclusively produced in industries mainly from Aspergillus niger (Slivinski et al., 2011; Dharani and Kumaran 2012; Gudi et al., 2013), A. oryzae (Zambare, 2010; Parbat and Singhal 2011; Sughanthi et al., 2011), A. awamori (Negi and Banerjee, 2010), A. flavus (Koc and Metin, 2010) and $A$. niveus (Maller et al., 2011) probably due to their ubiquitous nature and non-fastidious nutritional requirements. Solid state fermentation (SSF) is an old technology and has been used since 2600 BC.
However, in recent year SSF has emerged as a well developed biotechnological tool for the production of enzymes (Bhatnagar et al., 2010). The production of amylases in SSF is affected by a variety of physical factors, including the incubation temperature, $\mathrm{pH}$, aeration, particle size, age and size of inoculum. Therefore, after selecting a culture medium for amylase production, the fermentation conditions must be optimized to improve enzyme production at a low production cost (Dharani and Kumaran 2012).

Factorial experiments are commonly used in all research fields such as industrial biology, clinical science, social science, food science, physical and engineering science (Tekindal et al., 2012). The experimental design methodology is a very economic way for extracting the maximum amount of complex information, a significant experimental time saving factor and moreover, it saves the material used for analyses and personal costs as well. There is a relationship between the number of variables and the total cost of the experiment. As the number of variables increases, so does the number of design points 
required (Kincl et al., 2005). The factor effect is the change in the response variable for certain levels of the factors. In some experiments, due to interaction between factors, the difference in the response between the levels of one factor is not the same for all levels of another factor (Montgomery, 2001). The experiment investigates the effects of various combinations of two or more factors and their levels on the response variable. In factorial experiments, the main effects of the factors and their interaction are assessed (Siklar, 2000). The Box-Behnken experimental design, developed by Box and Behnken (1960), is a useful method for developing second-order response surface models. It is based on the construction of balanced incomplete block designs and requires at least three levels for each factor. In this experimental design, the level of one of the factors is fixed at the center level while combinations of all levels of the other factors are applied (Kocabas, 2001; Myers and Montgomery, 2002). In the present study, Box-Behnken factorial design was employed to investigate the effect of three most important physical parameters i.e., $\mathrm{pH}$, temperature and inoculum size on the production of GA from $A$. oryzae IIB6 in solid state fermentation. To our knowledge, use of RSM for the optimization of GA production has yet not been reported.

\section{MATERIALS AND METHODS}

\section{Chemicals}

The analytical grade chemicals used in the present study, were purchased directly from Sigma (USA), E-Merck (Germany), Acros (Belgium), Fluka (Switzerland) and $\mathrm{BDH}(\mathrm{UK})$.

\section{Microorganism and culture maintenance}

A. oryzae IIB-6 was isolated from soil samples collected from various localities of Doha (Qatar) as described previously (Fatima and Ali, 2012). It was propagated on PDA (4\%) slants, stored at $4{ }^{\circ} \mathrm{C}$ in cold cabinet (P342; Griffin) and renewed twice a month.

\section{Inoculum preparation}

Ten $\mathrm{mL}$ of sterilized $0.005 \%$ Monoxal-OT (Di-octylester of sodium sulpho succinic acid) were aseptically transferred to a 3-5 days old culture having profuse growth. The clumps of spores were broken with the help of a sterilized inoculating wire loop. The homogeneous suspension was made by gently shaking the tube.

\section{Measurement of viable spore density}

Equal volumes $(100 \mu \mathrm{L})$ of spore suspension and $0.4 \%$ trypan blue stain were mixed. For measurement of viable spore density, $10 \mu \mathrm{L}$ of this mixture was applied to haemocytometre (Marienfeld, Germany) and visualized under the microscope. The density of the spores was measured in accordance to Sharma (1989).

\section{Solid state fermentation}

Static cultures were established in $250 \mathrm{~mL}$ Erlenmeyer flasks containing wheat bran $7.4 \mathrm{~g}$ with $67 \%$ moisture level. The flasks were autoclaved (Model: KT-40L, ALP Co, Ltd 3-3-10, Midorigaoka, Hamara-shi Tokyo Japan) for $15 \mathrm{~min}$ at $121^{\circ} \mathrm{C}, 15 \mathrm{lbs} / \mathrm{in}^{2}$ pressures. Filter sterilized mineral salts solution containing additional trace elements $\mathrm{FeSO}_{4} \cdot 7 \mathrm{H}_{2} \mathrm{O} 0.0134 ; \mathrm{MgSO}_{4} \cdot 7 \mathrm{H}_{2} \mathrm{O}$ 0.67; $\left(\mathrm{NH}_{4}\right)_{2} \mathrm{SO}_{4} 2.68$; $\mathrm{KH}_{2} \mathrm{PO}_{4} 0.402 ; \mathrm{K}_{2} \mathrm{HPO}_{4} 0.938$ (mg/gds) was added at ambient temperature under aseptic conditions. The supplementary organic carbon and nitrogen sources (1\%) used were glucose, fructose, maltose, xylose, sucrose, lactose and tryptone, peptone, casein, yeast extract, malt extract, beef extract, respectively. The flasks were inoculated with $10 \% \quad(\mathrm{v} / \mathrm{w})$ spore suspension and incubated for $86 \mathrm{~h}$.

\section{Estimation of moisture contents}

Moisture contents (\%) of the substrate were estimated (Kunamneni et al., 2005) by drying various amounts of wheat bran to constant weight at $80 \pm 2{ }^{\circ} \mathrm{C}$ for $15 \mathrm{~min}$ in hot air oven (Model: 545804, Memmert 854 Schwabach Germany) and the dry weight was recorded. To fix the initial moisture content of the solid medium, the substrate was soaked with the appropriate quantity of mineral salts solution. The sample was then dried as described above and moisture content was calculated as follows:

Moisture conents $(\%)=\frac{(\text { wtof wheat bran-dry wt })}{d r y \text { wts }} \times 100$

\section{Extraction of enzyme}

At the end of fermentation, sodium acetate buffer $(0.05 \mathrm{M}$, $\mathrm{pH}$ 5) in a 1:10 ratio was added to individual Erlenmeyer flasks and agitated thoroughly on rotary shaking (200 rpm) incubator (Model: 10×400 XX2.C Sanyo Gallenkamp PLC, UK) for $60 \mathrm{~min}$ at $30 \pm 2{ }^{\circ} \mathrm{C}$ (Ghildyal et al., 1991). The contents were filtered through muslin cloth. The filtrate was centrifuged at $4 \pm 2{ }^{\circ} \mathrm{C}, 13,000 \mathrm{rpm}(25,900 \times \mathrm{g})$ for 15 min and the clear supernatant was used for further analysis.

\section{Enzyme assay}

GA was assayed according to Caldwell et al. (1968) and the amount of reducing sugar liberated was determined by 3, 5-dinitrosalicylic acid method (Miller, 1959) by measuring color intensity at $546 \mathrm{~nm}$ on a UV/VIS double beam scanning spectrophotometer (Cecil CE 100-series, Aquarius Inc., London, UK) using D-glucose as standard. One unit of activity was the amount of enzyme that liberates $1 \mathrm{mg}$ of glucose from $5 \%$ soluble starch at 60 ${ }^{\circ} \mathrm{C}, \mathrm{pH} 5.0$, per min and enzyme activity was expressed in term of units per gram dry substrate (U/gds). All experiments were carried out in triplicate and the average enzymatic activity was taken by CoStat 3.03 (CoHort software, Berkeley, CA94701). 


\section{Box-Behnken factorial design}

To investigate the cumulative effect of physical parameters viz. $\mathrm{pH}$, temperature and inoculum size experiments were carried out according to Box-Behnken factorial design. MINITAB-16 (PA, USA) was used to generate design with three factors and three levels, including three replicates at the centre point, resulting in total 15 treatment with combinations of independent variables $\mathrm{pH}$, temperature and inoculum size. The variables were investigated at three $(-1,0,+1)$ levels (Table 1) and were coded according to (Canettieri et al., 2007). The responses of the input variables were evaluated as a function of GA production coded by $\hat{Y}$ (U/gds). Predicted GA activity was calculated by a second order polynomial quadratic model:

$$
\hat{Y}=\beta_{\mathrm{o}}+\sum_{\mathrm{i}=1}^{k} \beta_{\mathrm{i}} x_{\mathrm{i}}+\sum_{\mathrm{i}=1}^{R} \beta_{\mathrm{ii}} x_{\mathrm{i}}^{2}+\sum_{\mathrm{i}, j=1} \beta_{\mathrm{i}} x_{\mathrm{i}} x_{j}+\varepsilon
$$

where, $\hat{Y}$ was the predicted response used as a dependent variable; $x i(i=1,2$ and 3$)$ were the input predictors; $\beta_{0}$ is the regression coefficient at center point; $\beta_{\mathrm{i}}(i=1,2$ and 3$)$ is the linear coefficient; $\beta_{\mathrm{ii}}(i=1,2$ and $3)$ is the quadratic coefficient; $\beta_{\mathrm{ij}}(i=1,2$ and 3 ; $j=i, \ldots \ldots \ldots, 3)$ is the second order interaction coefficient and $\varepsilon$ is the experimental error. The Student's $t$-test was employed to check the statistical significance of the regression coefficients. The Fisher's F-test for ANOVA was performed on experimental data to evaluate the statistical significance of the model.

Table 1: Range and levels of physical parameters of SSF process.

\begin{tabular}{lcccccc}
\hline Parameters & Code & Units & \multicolumn{5}{c}{ Range and level } \\
\cline { 4 - 7 } & & & -1 & 0 & +1 & $\Delta \mathrm{X}^{*}$ \\
\hline $\mathrm{pH}$ & $\mathrm{X} 1$ & - & 4 & 5.25 & 6.5 & 1.25 \\
Temperature & $\mathrm{X} 2$ & ${ }^{\circ} \mathrm{C}$ & 20 & 37.5 & 55 & 17.5 \\
Inoculum & $\mathrm{X} 3$ & $\%$ & 5 & 17.5 & 30 & 12.5
\end{tabular}

size

${ }^{*} \Delta \mathrm{X}$ is the increment of the experimental factor actual values corresponding to one unit of the coded variable.

\section{RESULTS AND DISCUSSION}

\section{Evaluation of additional carbon and nitrogen sources}

Wheat bran was supplemented with various organic carbon and nitrogen sources $(1 \% \mathrm{w} / \mathrm{w})$ to study their effect on enzyme production. Supplementation with maltose enhanced the GA production while all the other carbon sources adversely affected the enzyme synthesis (Figure 1A). Similar results were found when maltose $(1 \%)$ was used in the production of this enzyme from $A$. tamari (Moreira et al., 1999). It might be due to the fact that the other sugars used i.e. glucose, fructose, lactose and xylose are monosaccharides hence, act as only carbon sources to the growing culture while maltose is diasaccharide with two glucose units liked via a-1, 4glycosidic linkage, it acts not only as carbon source but also as an inducer. As the GA is an inductive enzyme that hydrolyzed $\alpha-1,4-$ glycosidic linkage faster than $\alpha-1,6$ and $\alpha-1,3$ linkages (Gudi et al., 2013) therefore, the addition of maltose enhanced the enzyme production. However, in sucrose, glucose and fructose are linked via $a-1, \beta-2-$ glycosidic linkage which cannot be hydrolyzed by the enzyme. Al-Ghanimi et al. (2007) used 1.5\% maltose as an inducer for the production of GA from $A$. ustus. However, Kareem et al. (2009) reported the adverse effect of maltose for the GA production from cowpea waste by $A$. oryzae. Lalitha et al. (2012) achieved maximum enzyme production on supplementing the corn cob residues with fructose but in the present study fructose was found to be least effective for the GA production. Hence, maltose was selected as best carbon source for the production of enzyme. Among the nitrogen sources (Figure 1B) peptone gave the highest enzyme activity. Yeast extract also increased the enzyme yield but $4.61 \%$ less than peptone. Similar increase in the yield of GA from $A$. niger growing in a solid-state fermentation on rice bran supplemented with peptone was reported by Pandey et al. (1994). Similarly, Balkan et al. (2011) observed less amylase activity with yeast extract as compared to peptone when they supplemented wheat bran with them at $1 \%$ concentration. Therefore, peptone was chosen as the best nitrogen source for the subsequent studies.
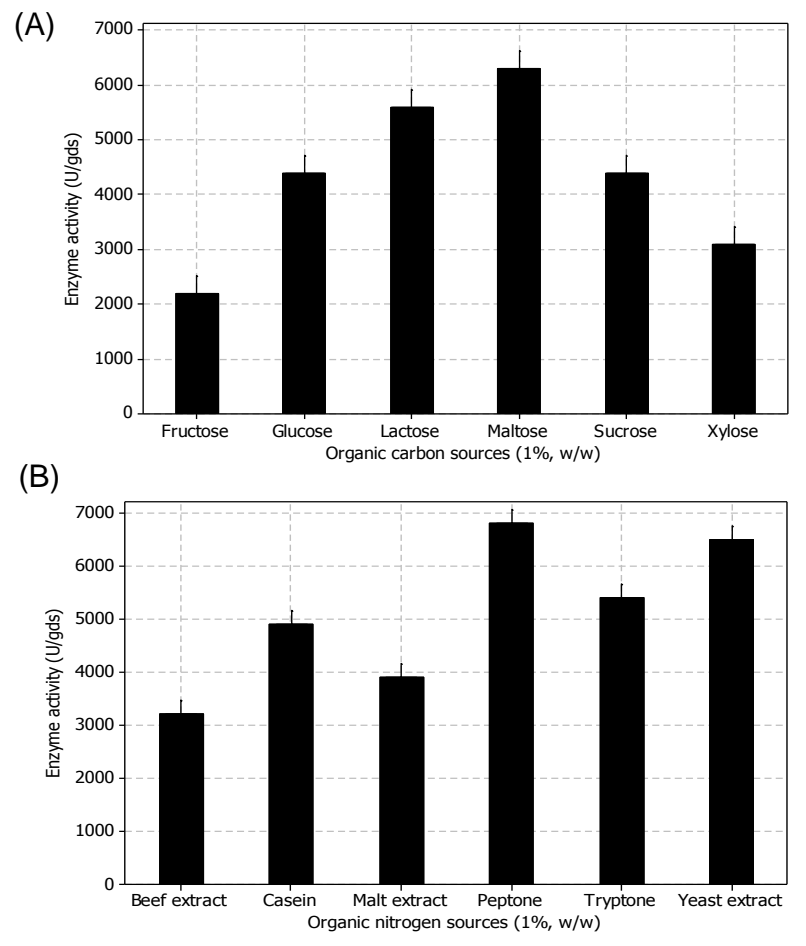

Figure 1: Effect of supplementary organic carbon (A) and nitrogen $(B)$ sources $(1 \% \mathrm{w} / \mathrm{w})$ after $86 \mathrm{~h}$ of incubation at $30 \pm 2{ }^{\circ} \mathrm{C}(\mathrm{pH} 5.0)$. Y-error bar shows standard error (S.E) among three parallel replicates $(n=3)$. 


\section{Optimization by response surface methodology}

\section{Box-Behnken factorial design}

Experiments were carried out to optimize the effects of process variables such as $\mathrm{pH}$, temperature and inoculum size for GA production according to Box-Behnken factorial design. For predicting the optimal level mathematically, second order polynomial regression model was fitted to the experimental results of GA production, as:

\section{$\hat{Y}=-18522.5+7637 X 1+179.8 X 2+314.9 X 3-720.1 X 1^{2}$ $2.5 \times 2^{2}-8.7 \times 3^{2}+0.2 \times 1 \times 2-1.2 \times 1 \times 3$}

The regression equation showed that GA production ( $\mathrm{U} / \mathrm{gds}$ ) is a function of $\mathrm{pH}$, temperature and inoculum size. Table 2 describes the process conditions and experimentally $(\mathrm{Y})$ measured enzyme activity (U/gds) with predicted $(\hat{Y})$ values. Experimental results showed maximum activity of $7712 \mathrm{U} / \mathrm{gds}$ while predicted value was $7708 \mathrm{U} / \mathrm{gds}$ (run number 10). The residual $(\mathrm{e}=3.33$ ) was due to few percentages of the total variations which could not be explained by the model.

Table 2: Box-Behnken factorial design of physical parameters of SSF in actual and coded units for the response of enzyme activity along with it's observed and predicted values.

\begin{tabular}{|c|c|c|c|c|c|c|}
\hline \multirow{2}{*}{$\begin{array}{l}\text { Run } \\
\text { No. }\end{array}$} & \multirow{2}{*}{$\begin{array}{l}\mathrm{pH} \\
(\mathrm{X} 1)\end{array}$} & \multirow{2}{*}{$\begin{array}{c}\text { Temperature }^{\circ} \mathrm{C} \\
\text { (X2) }\end{array}$} & \multirow{2}{*}{$\begin{array}{c}\text { Inoculum } \\
\text { size \% (X3) }\end{array}$} & \multicolumn{2}{|c|}{ Enzyme activity (U/gds) } & \multirow{2}{*}{$\begin{array}{l}\text { Residual } \\
\mathrm{e}=\mathrm{Y}-\hat{\mathrm{Y}}\end{array}$} \\
\hline & & & & $\begin{array}{c}\text { Observed } \\
\text { response }(\mathrm{Y})\end{array}$ & $\begin{array}{l}\text { Predicted } \\
\text { response }(\hat{Y})\end{array}$ & \\
\hline 1 & $4(-1)$ & $37.5(0)$ & $30(+1)$ & $5200 \pm 0.20$ & 5207 & -7 \\
\hline 2 & $6.5(+1)$ & $55(+1)$ & $17.5(0)$ & $5777 \pm 0.21$ & 5766 & 11 \\
\hline 3 & $4(-1)$ & $20(-1)$ & $17.5(0)$ & $5858 \pm 0.22$ & 5868 & -10 \\
\hline 4 & $5.25(0)$ & $37.5(0)$ & $17.5(0)$ & $7708 \pm 0.40$ & 7708 & 0 \\
\hline 5 & $4(-1)$ & $55(+1)$ & $17.5(0)$ & $5623 \pm 0.23$ & 5606 & 17 \\
\hline 6 & $6.5(+1)$ & $37.5(0)$ & $5(-1)$ & $5273 \pm 0.19$ & 5266 & 7 \\
\hline 7 & $5.25(0)$ & $55(+1)$ & $30(+1)$ & $5490 \pm 0.15$ & 5499 & -9 \\
\hline 8 & $6.5(+1)$ & $37.5(0)$ & $30(+1)$ & $5321 \pm 0.18$ & 5322 & -1 \\
\hline 9 & $5.25(0)$ & $55(+1)$ & $5(-1)$ & $5376 \pm 0.16$ & 5393 & -17 \\
\hline 10 & $5.25(0)$ & $37.5(0)$ & $17.5(0)$ & $7712 \pm 0.50$ & 7708 & 4 \\
\hline 11 & $6.5(+1)$ & $20(-1)$ & $17.5(0)$ & $5997 \pm 0.20$ & 6013 & -16 \\
\hline 12 & $5.25(0)$ & $37.5(0)$ & $17.5(0)$ & $7706 \pm 0.49$ & 7708 & -2 \\
\hline 13 & $4(-1)$ & $37.5(0)$ & $5(-1)$ & $5077 \pm 0.20$ & 5076 & 1 \\
\hline 14 & $5.25(0)$ & $20(-1)$ & $5(-1)$ & $5669 \pm 0.16$ & 5659 & 10 \\
\hline 15 & $5.25(0)$ & $20(-1)$ & $30(+1)$ & $5758 \pm 0.14$ & 5740 & 18 \\
\hline
\end{tabular}

${ }^{*} \pm$ indicates the standard deviation ( \pm S.D) of parallel replicates $(n=3)$. Each mean value differ significantly at $p \leq 0.05 \%$.

\section{Measurement of the effectiveness of the model}

A good estimated regression model should explain the variation of the dependent variable $(\mathrm{U} / \mathrm{gds})$ in the sample. There are certain tests (Figure 2 A-D) about the model parameters that can help the experimenter in measuring the effectiveness of the model. These tests require for the error term or residuals (e) to be normally and independently distributed with mean zero and variance. The normality of error may be examined by plotting a histogram of residuals (Figure 2C) or a normal probability plot (Figure 2A). Normal probability plots allow a more quantitative assessment of the normality of the distribution of residuals. In this study, the residuals are normally distributed along the straight line as shown in Figure $2 \mathrm{~A}$ so, the normality assumption is satisfied. The error term is the difference between observed values $(Y)$ and the corresponding predicted values $(\hat{Y})$. As a result of this assumption, observations are also normally and independently distributed. Figure 2 B indicates a constant variance showing that the variance was independent of GA production which again support the assumptions of the model. In this study, the value of correlation coefficient $\left(R^{2}\right)$ was 0.9999 and residual versus order plot (Figure 2D) look good, the data are randomly scattered around zero with no pattern which indicates a high level of correlation between experimental and predicted values. It was also indicated that $99.99 \%$ of the independent variables such as $\mathrm{pH}$, temperature and inoculum size were supported by the dependent variable or response in term of enzyme activity (U/gds). $R^{2}$ is also a valid measure for the fit of model and indicated that only $0.1 \%$ of the total variations were not explained by the model. The high value $(99.96 \%)$ of the adjusted $R^{2}$ also indicates a high significance of the model (Khuri and Cornell, 1987; Alam et al., 2008).

\section{Analysis of variance (ANOVA)}

The ANOVA results of response surface quadratic regression model for GA activity (U/gds) are given in Table 3. In general the $F$-value should be higher than $p$ value for the prediction to be significant. In this study, 
among the main, squared and interaction effects of the variables on the GA activity, the main and squared effects have very high $F$-values and low $p$-values $(<0.0001)$ which played a major role for GA production than the interaction effects which were insignificant. The lack-of-fit of the model also found to be insignificant which is strongly desirable for the adequate model.
(A)

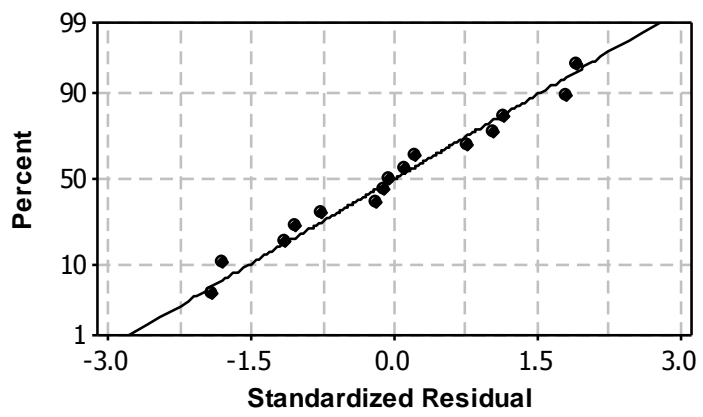

(C)

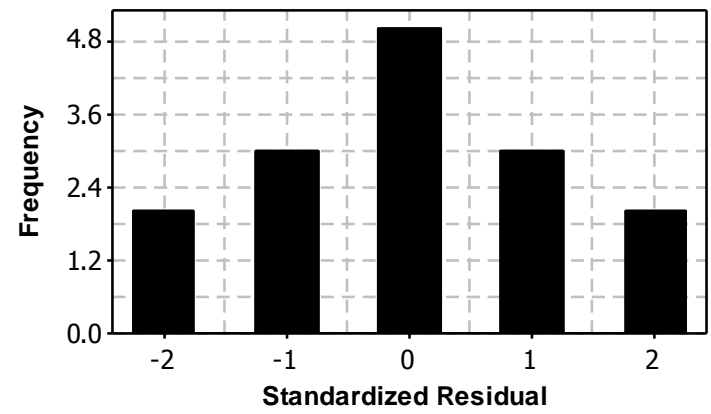

(B)

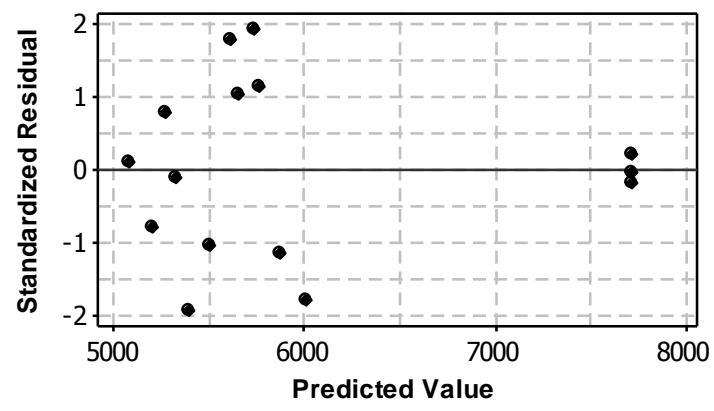

(D)

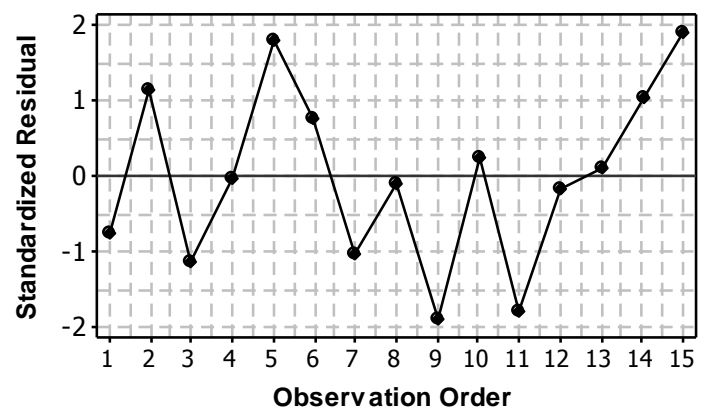

Figure 2: Standardized residual plots for the production of GA (U/gds) from $A$. oryzae IIB-6 in SSF. (A) Normal probability (\%) plot. (B) Standardized residual versus predicted values. (C) Standardized residual versus frequency. (D) Standardized residual versus observed order.

Table 3: ANOVA for response surface quadratic regression model of enzyme activity (U/gds).

\begin{tabular}{|c|c|c|c|c|c|c|}
\hline Source & $\begin{array}{l}\text { Degree of } \\
\text { freedom }\end{array}$ & $\begin{array}{l}\text { Seq sum of } \\
\text { square }\end{array}$ & $\begin{array}{l}\text { Adj sum of } \\
\text { square }\end{array}$ & $\begin{array}{l}\text { Adj mean } \\
\text { square }\end{array}$ & $F$-value & $p$-value \\
\hline Regression & 9 & 1225435 & 12254350 & 1361594 & 4194.25 & $<0.0001^{* \star}$ \\
\hline Linear & 3 & 193029 & 5811437 & 1937146 & 5967.18 & $<0.0001^{* *}$ \\
\hline Square & 3 & 12059702 & 12059702 & 4019901 & 12382.9 & $<0.0001^{* *}$ \\
\hline Interaction & 3 & 1619 & 1619 & 540 & 1.66 & $0.289^{*}$ \\
\hline $\begin{array}{l}\text { Residual } \\
\text { error }\end{array}$ & 5 & 1623 & 1623 & 325 & & \\
\hline Lack-of-fit & 3 & 1604 & 1604 & 535 & 57.30 & $0.17^{*}$ \\
\hline Pure error & 2 & 19 & 19 & 9 & & \\
\hline Total & 14 & 12255073 & & & & \\
\hline
\end{tabular}

$\mathrm{R}-\mathrm{Sq}=99.99 \%, \mathrm{R}-\mathrm{Sq}(\mathrm{pred})=99.79 \%, \mathrm{R}-\mathrm{Sq}(\mathrm{adj})=99.96 \%,{ }^{*}$ Non-significant at $p>0.05 \%,{ }^{*}$ Significant at $p<0.05 \%$

Main and interactive effects of physical parameters on enzyme production under SSF

In order to determine whether given model terms should be included or discluded from the model, it needs to test the individual regression co-efficient. Figure $3 \mathrm{~A}$ depicts the main effects of $\mathrm{pH}$, temperature and inoculum size on the GA activity. Each individual variable increases the individual regression co-efficient. Each individual variable increases the response with increasing their level up to a certain extent and then further increase in variable level gradually decreases the response. Alternatively, 
$\mathrm{pH}$ and inoculum size individually appear to have a greater effect on the GA activity (U/gds). Consequently, the levels of these variables appear to have a greater effect on the response, hence the levels of each variable's mean values are given in Table 4. Moreover, the quadratic terms and the interaction terms significantly contributed to the response model. For an interaction effect to be significant, at least one of its parent variable should be significant (Wu, 2000). This fundamental principle for factorial effects is called effect heredity principle. Since all the three parent main variables are identified as significant, so any of the interaction between the main effects cannot be rule out. Interaction plots are shown in Figure $3 \mathrm{~B}$ and each pair of variables provided the following results:

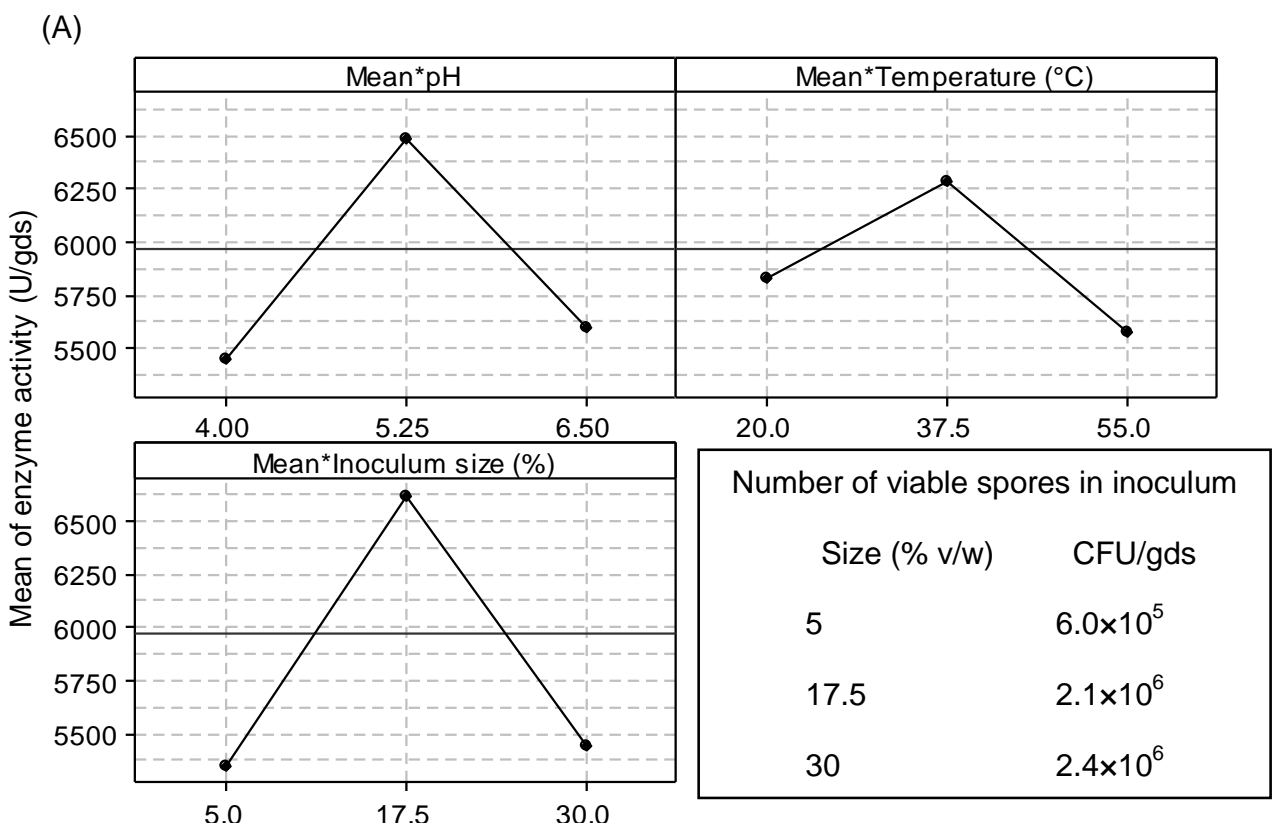

(B)

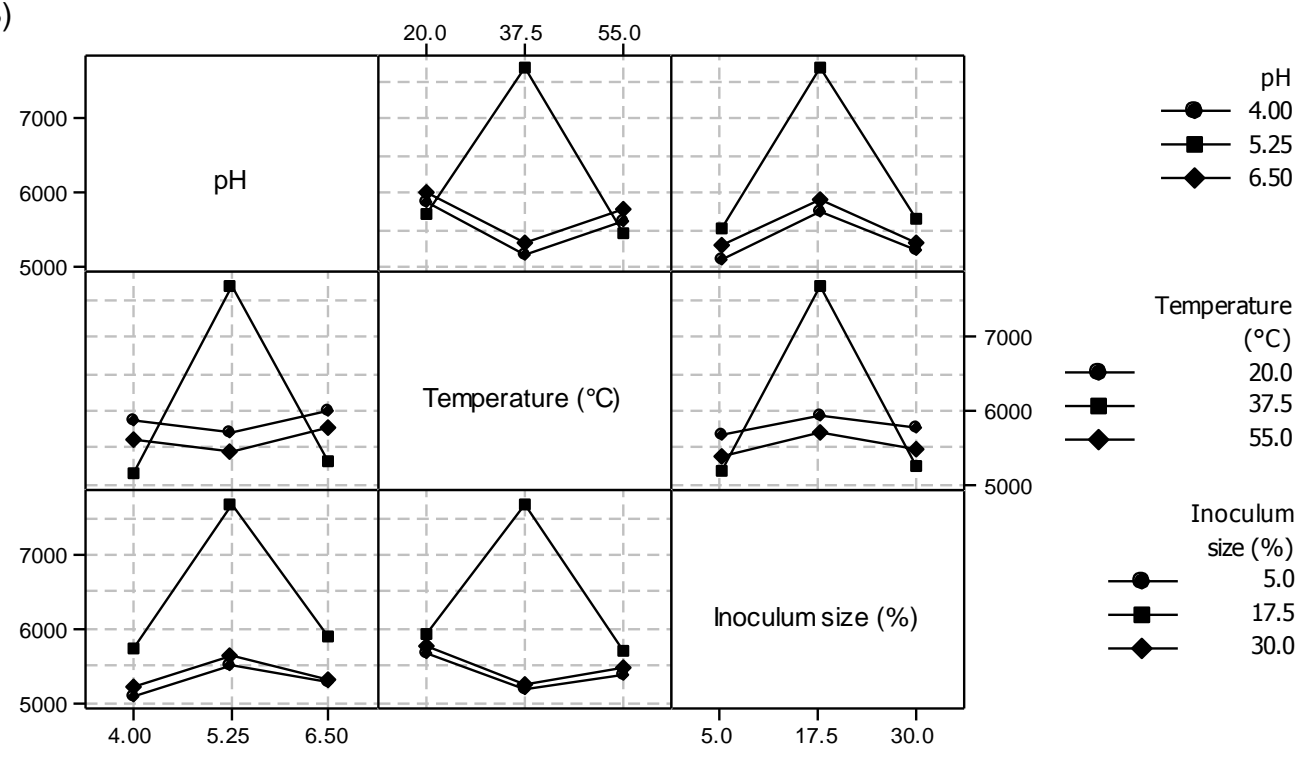

Figure 3: Main (A) and interaction (B) effect plots (Data mean) for GA production (U/gds) from A. oryzae IIB-6 in SSF. 
Table 4: Mean values of each level of variables.

Mean values of $\mathrm{X} 1(\mathrm{pH})$

\begin{tabular}{llll}
\hline & & & \\
& & & \\
Level & $N$ & Mean & St. Dev \\
4.00 & 4 & 5439.5 & 364.0 \\
5.25 & 7 & 6488.4 & 1147.9 \\
6.50 & 4 & 5592.0 & 352.8
\end{tabular}

Individual 95\% Cls For Mean Based on

Pooled St. Dev.

Enzyme activity (U/gds)

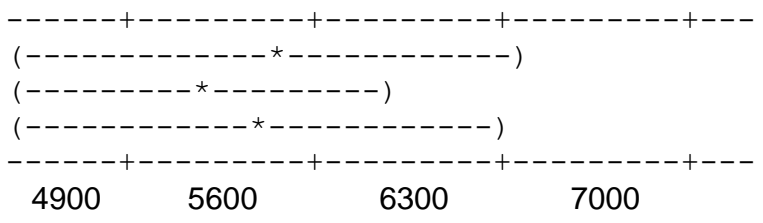

Pooled St. Dev. = 850.4

Mean values of $\mathrm{X} 2\left(\right.$ Temperature $\left.^{\circ} \mathrm{C}\right)$

Individual 95\% Cls For Mean Based on

Pooled St. Dev.

$\begin{array}{llll}\text { Level } & \text { N } & \text { Mean } & \text { St. Dev. } \\ 20.0 & 4 & 5820.5 & 140.7 \\ 37.5 & 7 & 6285.3 & 1333.6 \\ 55.0 & 4 & 5566.5 & 172.9\end{array}$

Enzyme activity (U/gds)

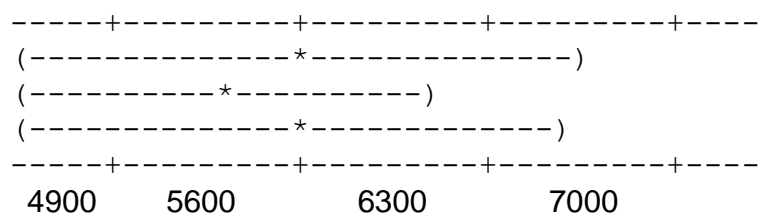

Pooled St. Dev. $=949.5$

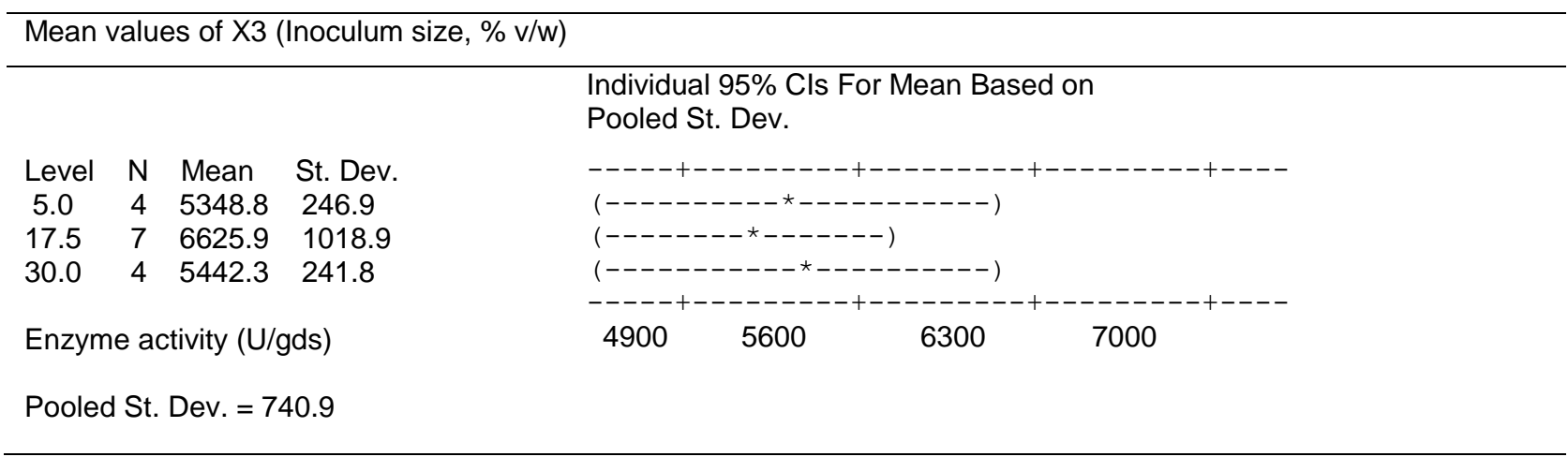

X1X2: The interaction of $\mathrm{pH}(\mathrm{X} 1)$ at levels of $4,5.25,6.4$ and temperature (X2) at levels of $20,37.5,55^{\circ} \mathrm{C}$ showed that at temperature $20^{\circ} \mathrm{C}$, the $\mathrm{pH}$ at all levels gave almost same GA production, but when the temperature increases to $37.5^{\circ} \mathrm{C}$, the $\mathrm{pH} 4$ and 6.4 level decreases the enzyme production. However, at the same temperature, the $\mathrm{pH}$ 5.25 gave maximum enzyme activity. A further increase in temperature to $55{ }^{\circ} \mathrm{C}$, resulted in same enzyme production at all the three levels of $\mathrm{pH}$ as was attained at $20{ }^{\circ} \mathrm{C}$. The same trend was observed by all the three levels of temperature at each level of $\mathrm{pH}$.

X1X3: The cumulative effect of $\mathrm{pH}(\mathrm{X} 1)$ at levels of 4, $5.25,6.4$ and inoculum size at the levels of $5,17.5,30 \%$, showed that at $\mathrm{pH} 4$, the inoculum levels 5 and $30 \%$ gave low enzyme production as compared to $17.5 \%$. When the $\mathrm{pH}$ was increased to 5.25 , the enzyme activity was also increased at 5 and $30 \%$ levels of inoculum but this increase was not very prominent. However, $17.5 \%$ inoculum level increased the enzyme production to a large extent at the same $\mathrm{pH}$. Further increase in $\mathrm{pH}$ up to 6.5 decreased the enzyme activity at all inoculum levels. The same trend was observed by all the three levels of $\mathrm{pH}$ at each level of inoculum size.

X2X3: The mutual interaction between temperature (X2) at levels of $20,37.5,55^{\circ} \mathrm{C}$ and inoculum size (X3) at levels of $5,17.5,30 \%$ showed that at temperature $20^{\circ} \mathrm{C}$, inoculum size at all the three levels gave almost same enzyme activity. When temperature raised to $37.5{ }^{\circ} \mathrm{C}$, 
enzyme activity was decreased at inoculum levels 5 and $30 \%$, but it was increased and became maximum at the same temperature when inoculum at the level of $17.5 \%$ was used. Further increase in temperature upto $55{ }^{\circ} \mathrm{C}$, decreases the enzyme activity at all levels of inoculum. On the other hand, when inoculum level was 5\%, almost same enzyme production was observed at all the temperature levels. By increasing the inoculum level to $17.5 \%$ enzyme activity was also increased and became maximum at $37.5^{\circ} \mathrm{C}$. Further increase in inoculum level upto $30 \%$ decreases the enzyme activity at all temperature levels.

\section{Least square multiple regression}

The main and interaction plots are helpful in visualizing which variable/s individually or in combination affect the response most. But in order to determine the significance of the variables, an appropriate statistical test " $t$-test" under least square multiple regression was employed to analyze the variability of data (Table 5). The main effects of $\mathrm{pH}$, temperature and inoculum size were very significant $(p<0.0001)$ and all these variables increases the GA production as they have large positive $t$ values. The sign of " $t$ " imply the impact of their effects on enzyme activity. The squared or quadratic effects of all the variables were also very significant $(p<0.0001)$ but they have negative impact on enzyme production. The interaction effects of all the variables were non-significant $(p>0.05 \%)$. Further the interaction effect $X 2 X 3$ between temperature (X2) and inoculum size (X3) have zero coefficient value so was excluded from the model.

Table 5: Co-efficient of main and interaction effects of the variables estimated by multiple linear regression.

\begin{tabular}{|c|c|c|c|c|}
\hline $\begin{array}{l}\text { Independent } \\
\text { variables }\end{array}$ & Co-efficient $(\beta)$ & $\begin{array}{l}\text { Standard error co- } \\
\text { efficient }\end{array}$ & $t$-value & $p$-value \\
\hline Constant & -18522.5 & 199.543 & -92.824 & $<0.0001^{* *}$ \\
\hline $\mathrm{X} 1$ & 7637.0 & 65.853 & 115.969 & $<0.0001^{\star *}$ \\
\hline $\mathrm{X} 2$ & 179.8 & 3.256 & 55.239 & $<0.0001^{* *}$ \\
\hline X3 & 314.9 & 4.027 & 78.189 & $<0.0001^{* *}$ \\
\hline$X 1^{2}$ & -720.1 & 6.001 & -120.001 & $<0.0001^{* *}$ \\
\hline$\times 2^{2}$ & -2.5 & 0.031 & -82.088 & $<0.0001^{* *}$ \\
\hline$\times 3^{2}$ & -8.7 & 0.660 & -145.650 & $<0.0001^{* *}$ \\
\hline $\mathrm{X} 1 \mathrm{X} 2$ & 0.2 & 0.412 & 0.416 & $0.694^{*}$ \\
\hline$X 1 X 3$ & -1.2 & 0.577 & -2.081 & $0.092^{*}$ \\
\hline$\times 2 \times 3$ & 0.0 & 0.041 & 0.694 & $0.529^{*}$ \\
\hline
\end{tabular}

${ }^{*}$ Non-significant at $p>0.05 \%,{ }^{\star \star}$ Significant at $p<0.05 \%$

\section{Graphical representation}

The relationship between independent and dependent variables was graphically represented by $2 D$ (Figures $3 A$ $5 \mathrm{~A}$ ) counter and 3D (Figures 3B-5B) response surface plots generated by the model. Different shapes of the contour plots indicated different interactions between the variables, an elliptical contour plot indicated the significant interactions between the variables while a circular contour plot means otherwise (Zhao et al., 2012). There are remarkable changes, which occur due to the $\mathrm{pH}$ of the substrates. These are mainly the production of acids due to incomplete oxidation of the substrate or uptake of ammonium ions, which cause the $\mathrm{pH}$ to fall, while the release of ammonia by deamination increases the $\mathrm{pH}$. Similarly, microbial growth in SSF generates significant amount of metabolic heat. It has been reported that 100$300 \mathrm{~kJ}$ of heat per $\mathrm{kg}$ of cell mass is generated in a SSF process. Temperature rises rapidly, because there is little water to absorb the heat or in other words mean specific heat capacity of the fermenting mass is much lower than that of water. Therefore, establishment of $\mathrm{pH}$ and temperature gradients for the optimal production of enzyme are very important (Manpreet et al., 2005). Figure $4 \mathrm{~A}$ shows the interaction of $\mathrm{pH}(\mathrm{X} 1)$ and temperature (X2) on enzyme yield when inoculum size was fixed at $17.5 \%$. Increase in $\mathrm{pH}$ from 4 to 5.2 , improve the enzyme production. However, when $\mathrm{pH}$ was over 5.2, there was a gradual decline in the response and incubation temperature over $36^{\circ} \mathrm{C}$ did not show any obvious effect on enzyme yield. The optimal GA yield was 7715.11 $\mathrm{U} / \mathrm{gds}$ achieved at pH 5.29 and temperature 36.21 as predicted by point prediction method (Figure 4B). Figure $5 \mathrm{~A}$ shows the interaction of $\mathrm{pH}(\mathrm{X} 1)$ and inoculum size (X3) on enzyme production when temperature was fixed at $37.5^{\circ} \mathrm{C}$. By increasing the $\mathrm{pH}$ from 4 to 5.2 , enzyme production was also increased. However, further increase in $\mathrm{pH}$ gradually decreased the enzyme activity. Similarly, enzyme yield was increased with the increase of inoculum size from 5 to $17 \%$ and but over $17 \%$ gradual decrease in enzyme production was observed. The maximum GA production was $7710.35 \mathrm{U} / \mathrm{gds}$ achieved at $\mathrm{pH} 5.29$ with inoculum size of $17.7 \%$ (Figure $5 B$ ). Figure $6(A)$ depicts the interaction of temperature (X2) and inoculum size (X3) by keeping the $\mathrm{pH}(\mathrm{X} 1)$ at 5.25 . The enzyme production was increased by increasing the incubation temperature from 20 to $36{ }^{\circ} \mathrm{C}$ which decreased over $36{ }^{\circ} \mathrm{C}$. The inoculum size over $17.5 \%$ did not show any improvement in enzyme yield. The optimum enzyme activity was $7713.67 \mathrm{U} / \mathrm{gds}$ at temperature $36.22{ }^{\circ} \mathrm{C}$ and $17.96 \%$ of inoculum size (Figure 6B). Varzakas et al. (2008) optimized $2 \times 10^{7}$ conidia/gds and $37^{\circ} \mathrm{C}$ for the production of enzyme from $A$. niger. Bhatti et al. (2007) reported inoculum size of $15 \%(\mathrm{w} / \mathrm{v})$ with $10^{6}-10^{7}$ spores $/ \mathrm{mL}$, 
incubation temperature of $35 \pm 1{ }^{\circ} \mathrm{C}$ and $\mathrm{pH} 5.0$ for the production of enzyme from Fusarium solani by using wheat bran. A. oryzae HS-3 showed optimum productivity in a temperature range of $30-40{ }^{\circ} \mathrm{C}$ on wheat bran (Singh and Soni, 2001).

(A)

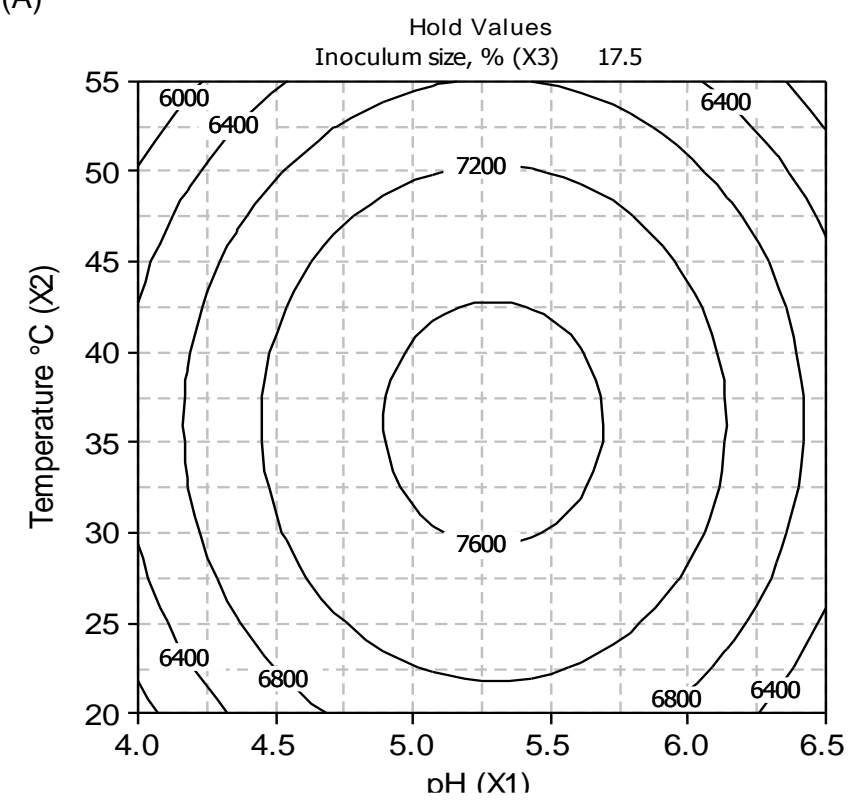

(B)

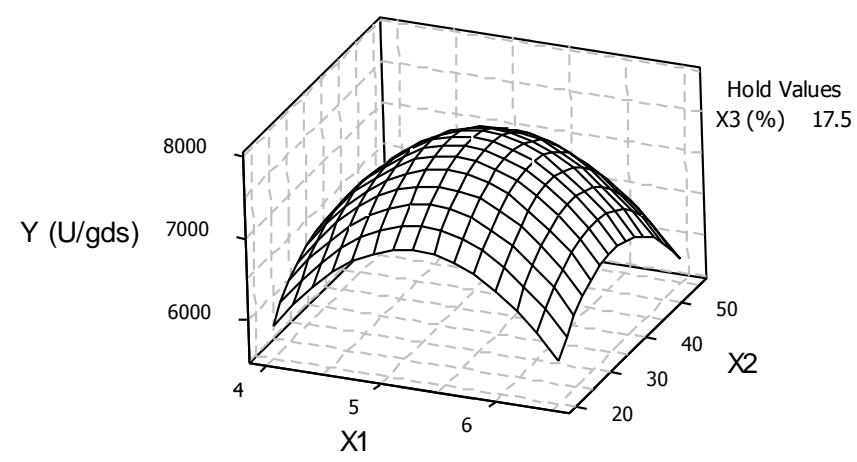

Figure 4: Counter plot $(A)$ and response surface plot $(B)$ for the production of $\mathrm{GA}(\mathrm{U} / \mathrm{gds})$ from $A$. oryzae IIB-6 showing the interactive effect of $\mathrm{pH}(\mathrm{X} 1)$ and temperature (X2) in SSF by keeping inoculum size (X3) at central level. 
(A)

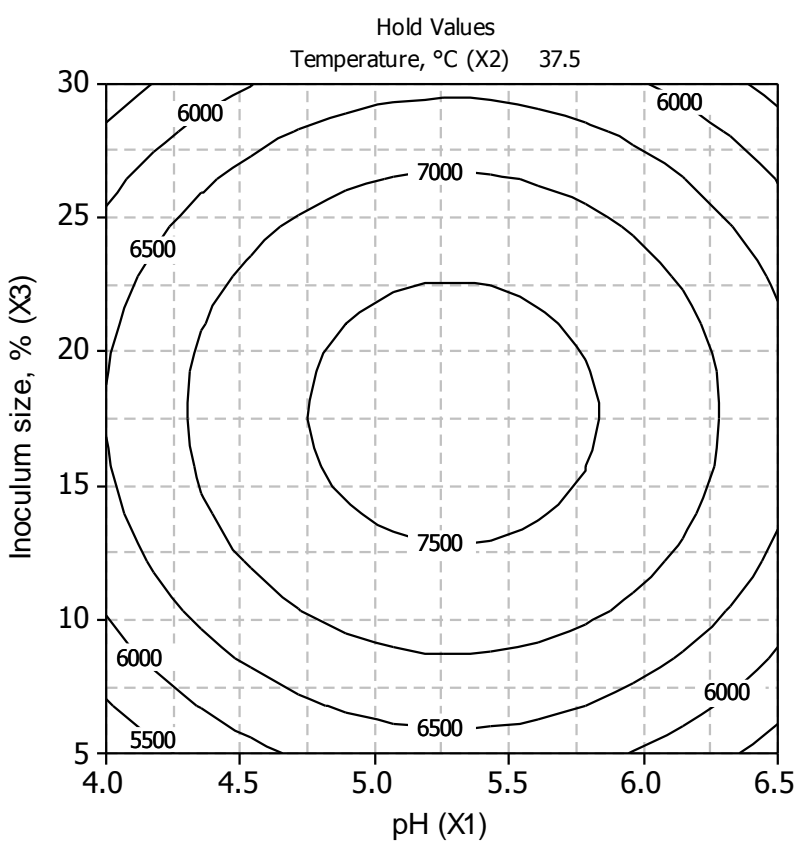

(B)

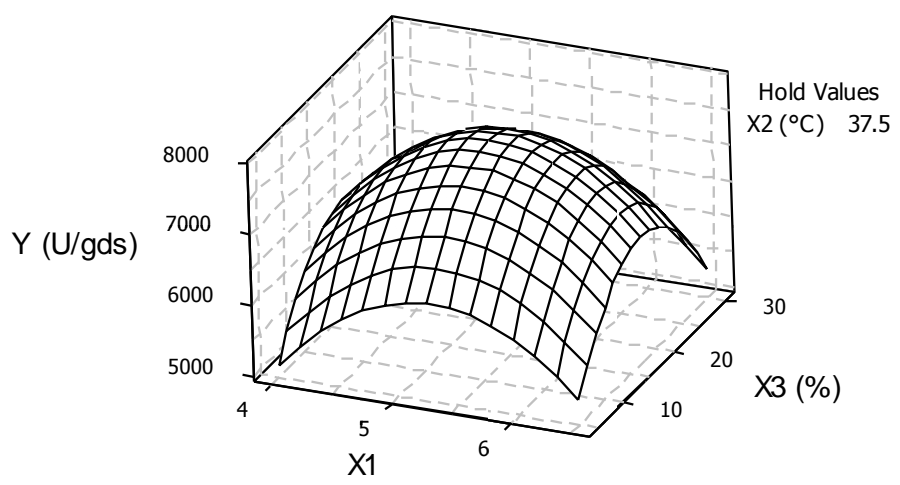

Figure 5: Counter plot $(\mathrm{A})$ and response surface plot $(\mathrm{B})$ for the production of $\mathrm{GA}(\mathrm{U} / \mathrm{gds})$ from $A$. oryzae IIB-6 showing the interactive effect of $\mathrm{pH}(\mathrm{X} 1)$ and inoculum size (X3) in SSF by keeping temperature (X2) at central level. 
(A)

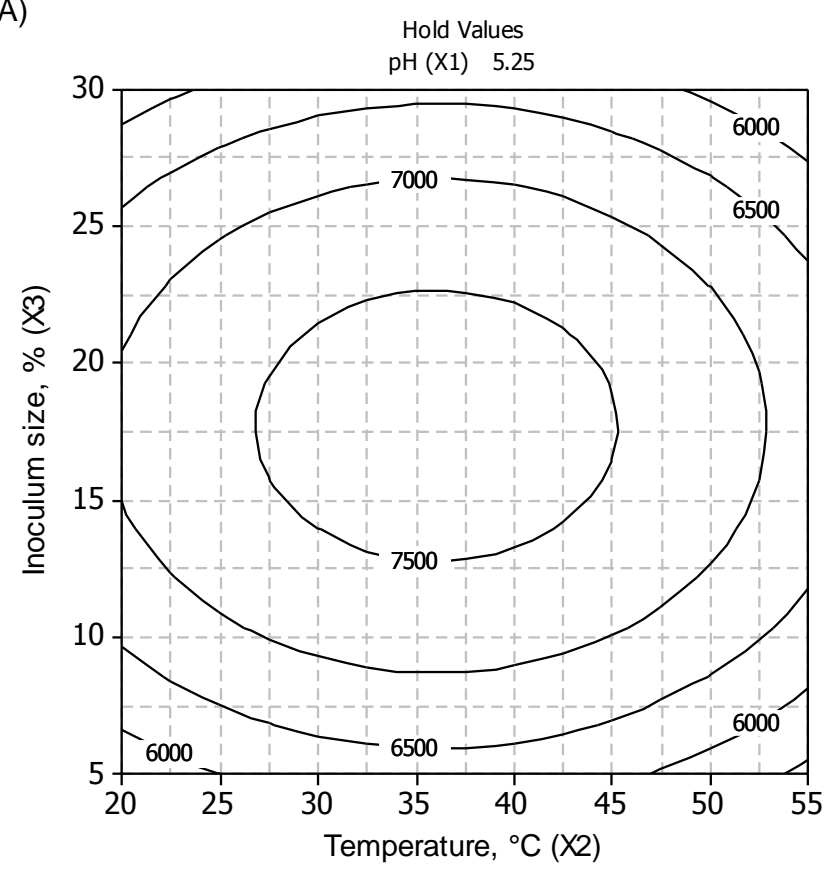

(B)

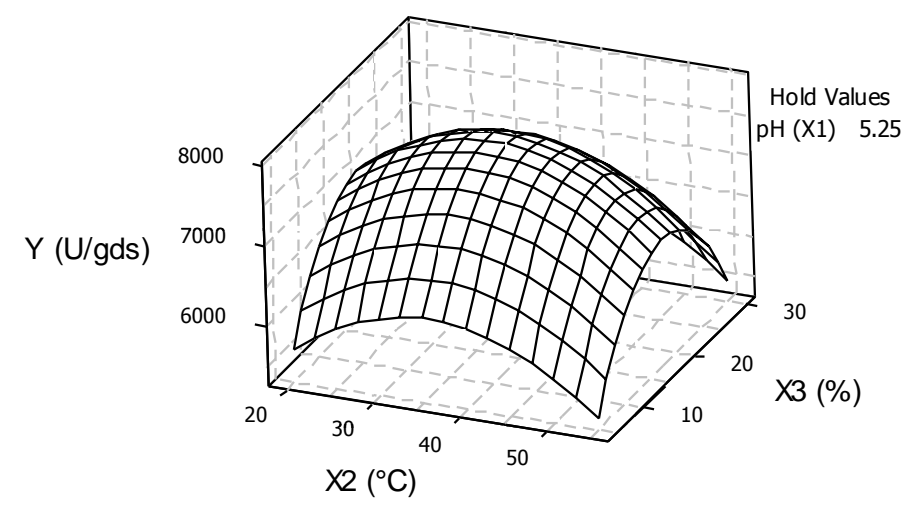

Figure 6: Counter plot (A) and response surface plot (B) for the production of GA (U/gds) from A. oryzae IIB-6 showing the interactive effect of temperature (X2) and inoculum size (X3) in SSF by keeping pH (X1) at central level. 


\section{Model validation}

With the help of counter plots and point prediction the optimum value of the combination of the three fermentation variables was determined for maximum production of enzyme. In order to verify the optimization results and to validate the developed second order quadratic model, an experiment was conducted under predicted conditions (Table 6). The closeness of the predicted response for GA (7713.04 U/gds) and the experimental response $(7750.02 \mathrm{U} / \mathrm{gds})$ proved the validity of the model. This indicated that the optimization achieved in the present study was reliable.

Table 6: Predicted and experimental value of responses at optimum conditions.

\begin{tabular}{lllll}
\hline $\begin{array}{l}\text { Optimum } \\
\text { conditions }\end{array}$ & $\mathrm{pH}$ & Temperature $\left({ }^{\circ} \mathrm{C}\right)$ & Inoculum size (\%) & GA activity (U/gds) \\
\hline $\begin{array}{l}\text { Predicted } \\
\text { Actual }\end{array}$ & 5.29 & 36.22 & 17.70 & 7713.04 \\
\hline
\end{tabular}

Standard error $($ S.E) $=18.5$

\section{CONCLUSION}

Maltose and peptone were found as the best additional carbon and nitrogen supplements of wheat bran for GA production. Application of RSM for optimization studies is an effective method for improving the enzyme production and also understanding the interaction effects between the variables with less number of experiments. BoxBehnken factorial design was successfully employed to optimize physical parameters of SSF. Under optimal conditions, GA activity of $7750.02 \mathrm{U} / \mathrm{gds}$ was obtained and it is closer to the predicted value. Additionally, an $R^{2}$ of 0.9999 indicates that the regression equation explains $99.99 \%$ of the variance in the dependent variables.

\section{REFERENCES}

Alam, M. Z., Jamal, P. and Nadzir, M. M. (2008). Bioconversion of palm oil mill effluent for citric acid production: statistical optimization of fermentation media and time by central composite design. World Journal of Microbiology Biotechnology 24, 1177-1185.

Al-Ghanimi, A. A., Al-Ethari, A. Y. and Al-Ahmar, S. D. (2007). Effect of cultural conditions on the production of glucoamylase from Aspergillus ustus. Jounal of Kerbala University 5(2), 61-68.

Balkan, B., Balkan, S. and Ertan, F. (2011). Optimization of parameters for a-amylase production under solid state fermentation by Trichothecium roseum. Romanian Biotechnology Letters 16(5), 6591-6600.

Bhatnagar, D., Joseph, L. and Raj, R. P. (2010). Amylase and acid protease production by solid state fermentation using Aspergillus niger from mangrove swamp. Indian Journal of Fisheries 57(1), 45-51.

Bhatti, H. N., Rashid, M. H., Nawaz, R., Asgher, M., Perveen, R. and Jabbar, A. (2007). Optimization of media for enhanced glucoamylase production in solid-state fermentation by Fusarium solani. Food Technology and Biotechnology 45(1), 51-56.

Box, G. E. P. and Behnken, D. W. (1960). Some new three level designs for the study of quantitative variables. Technometrics 2(4), 455-475.
Caldwell, K. D., Roff, A., Margereta, B. and Jerker, P. (1968). Estimation of amyloglucosidase. Biotechnology Bioengineering 18, 1592.

Canettieri, E. V., Rocha, G. J. D. M., De-Carvalho, J. A. and Silva, J. B. D. A. E. (2007). Optimization of acid hydrolysis from the hemicellulosic fraction of eucalyptus grandis residue using response surface methodology. Bioresource Technology 98, 422-428.

Dharani G. and Kumaran, N. S. (2012). Amylase production from solid state fermentation and submerged liquid fermentation by Aspergillus niger. Bangladesh Journal of Science and Industrial Research 47(1), 99-104.

Fatima, B. and Ali, S. (2012). Kinetics of improved 1,4alpha-D-glucan glucohydrolase biosynthesis from a newly isolated Aspergillus oryzae IIB-6 and parameter significance analysis by 2 -factorial design. Springer Plus 1, 32. doi:10.1186/2193-1801-1-32

Ghildyal, N. P., Ramakrishna, M., Lonsane, B. K. and Karanth, N. G. (1991). Efficient and simple extraction of mouldy bran in a pulsed column extractor for recovery of amyloglucosidase in concentrated form. Process Biochemistry 26, 235-241.

Gudi, S. K., Gurramkonda, C., Rather, G., Chandra, M. G. S., Mangamuri, U. K., Podha, S. and Choi, Y. L. (2013). Glucoamylase from a newly isolated Aspergillus niger FME: Detergent-Mediated production, purification and characterization. Journal of the Korean Society for Applied Biological Chemistry 56, 427-433.

Kareem, S. O., Akpan, I. and Oduntan, S. B. (2009). Cowpea waste: A novel substrate for solid state production of amylase by Aspergillus oryzae. African Journal of Microbiolgy Research 3(12), 974-977.

Khuri, A. I. and Cornell, J. A. (1987). Response surfaces: design and analysis. Marcel Decker Inc., New York. pp. 165-170.

Kincl, M., Turk, S. and Vrecer, F. (2005). Application of experimental design methodology in development and optimization of drug release method. International Journal Pharmaceitics 291, 39-49.

Koc, O. and Metin, K. (2010). Purification and characterization of a thermostable glucoamylase 
produced by Aspergillus flavus HBF34. African Journal of Biotechnology 9(23), 3414-3424.

Kocabaş, Z. (2001). An application and interpretation of second order response surface model. Journal of Agricultural Science 7, 121-128.

Kunamneni, A., Kumar, K. S. and Singh, S. (2005). Response surface methodological approach to optimize the nutritional parameters for enhanced production of $\alpha$-amylase in solid state fermentation by Thermomyces lanuginosus. African Journal of Biotechnology 4(7), 708-716.

Lalitha, P., Shravya, K. and Arunalakshmi, K. (2012). Effect of supplementary carbon and nitrogen sources on amylase production by Trichoderma viride in solid state fermentation. International Journal Life Science Biotechnology and Pharmaceutical Research 1(1), 160-163.

Maller, A., Damasio, A. R. L., da-Silva, T. M., Jorge, J. A., Terenzi, H. F., de-Lourdes, M. M. and Polizeli, T. M. (2011). Biotechnological potential of agroindustrial wastes as a carbon source to thermostable polygalacturonase production in Aspergillus niveus. Enzyme Research doi:10.4061/2011/289206.

Manpreet, S., Sawraj, S., Sachin, D., Pankaj, S. and Banerjee, U. C. (2005). Influence of process parameters on the production of metabolites in solidstate fermentation. Malalaysian Journal of Microbiology 1(2), 1-9.

Miller, G. L. (1959). Use of dinitrosalicylic acid reagent for the determination of reducing sugars. Journal of Analytical Chemistry 31, 426-428.

Montgomery, D. C. (2001). Design and analysis of experiments. $5^{\text {th }}$ edn. A Wiley-Interscience Publication, John Wiley and Sons, Canada. pp. 427510.

Moreira, F. G., Lima, F. A., Pedrinho, S. R. F., Lenartovicz, V., Souza, C. G. M. and Peralta, M. (1999). Production of amylase by Aspergillus tamarii. Review Microbiology 30(2), 157-162.

Myers, R. H. and Montgomery, D. C. (2002). Response surface methodology process and product optimization using designed experiments. $2^{\text {nd }}$ edn. A Wiley-Interscience Publication, John Wiley and Sons, Canada. pp. 17-85, 203-303.

Negi, S. and Banerjee, R. (2010). Optimization of culture parameters to enhance production of amylase and protease from Aspergillus awamori in a single fermentation. African Journal of Biochemistry Research 4(3), 73-80.

Pandey, A., Selvakumar, P. and Ashakumary, L. (1994). Glucoamylase production by Aspergillus niger on rice bran is improved by adding nitrogen sources. World Journal of Microbiology and Biotechnology 10(3), 348-349.

Parbat, R. and Singhal, B. (2011). Production of glucoamylase by Aspergillus oryzae under solid state fermentation using agro industrial products. International Journal of Microbiological Research 2(3), 204-207.
Sharma, P. D. (1989). Methods in microbiology and plant pathology. Rastogi and Company, Meerut, India. pp. 33-35.

Siklar, E. (2000). Introduction to regression analysis. $1^{\text {st }}$ ed. Anadolu University Publications No: 1255, Faculty of Science Publication No. 16, eds. CIP-Anadolu University Library and Documentation Centre, Eskişehir, Turkey. pp. 50-76.

Singh, H. and Soni, S. K. (2001). Production of starch gel digesting amyloglucosidase by Aspergillus oryzae HS-3 in solid-state fermentation. Process Biochemistry 37, 453-59.

Slivinski, C. T., Machado, A. V. L., Lulek, J., Ayub, R. A. and de-Almeida, M. M. (2011). Biochemical characterization of a glucoamylase from Aspergillus niger produced by solid-state fermentation. Brazilian Archives of Biology and Technology 54(3), 559-568.

Suganthi, R., Benazir, J. F., Santhi, R., Kumar, R. V., Hari, A., Meenakshi, N., Nidhiya, K. A., Kavitha, G. and Lakshmi, R. (2011). Amylase production by Aspergillus niger under solid-state fermentation using agroindustrial wastes. International Journal of Engineering Science and Technology 3, 1756-1763.

Tekindal, M. A., Bayrak, H., Ozkaya, B. and Genc, Y. (2012). Box-Behnken experimental design in factorial experiments: The importance of bread for nutrition and health. Turkish Journal of Field Crops 17(2), 115-123.

Varzakas, T. H., Roussos, S. and Arvanitoyannis, I. S. (2008). Glucoamylases production of Aspergillus niger in solid state fermentation using a continuous counter-current reactor. International Journal of Food Science and Technology 43, 1159-1168.

Wu, C. F. and Michael, H. (2000). Experiments: Planning, analysis, and parameter design optimization. Wiley Interscience, New York. pp.106-110.

Zambare, V. (2010). Solid state fermentation of Aspergillus oryzae for glucoamylase production on agro-residues. International Journal Life Science 4, 16-25.

Zhao, L. C., He, Y., Deng, X., Yang, G. L., Li, W., Liang, J. and Tang, Q. L. (2012). Response surface modeling and optimization of accelerated solvent extraction of four lignins from Fructus schisandrae. Molecules 17, 3618-3629. 